DEIFGA LATA

Jurnal Ilmu Hukum

FAKULTAS HUKUM UMSU

\title{
PENUNTUTAN REQUISTOIR BAGI PELAKU TINDAK PIDANA NARKOTIKA
}

\author{
Fauzi Iswahyudi \\ Kantor Wilayah Kementerian Hukum dan HAM Provinsi Sumatera Utara \\ Jl. Putri Hijau Medan - Sumatera Utara \\ Email: fauziiswahyudi@gmail.com
}

\begin{abstract}
Abstrak
Penuntutan atas suatu peristiwa atau tindak pidana, termasuk kejahatan narkotika adalah fungsi yang dilakukan oleh Kantor Kejaksaan, dalam hal ini oleh penuntut umum. Penuntutan adalah tindakan penuntut umum yang mendelegasikan kasus pidana ke pengadilan distrik yang kompeten dalam hal dan sesuai dengan metode yang diatur dalam KUHAP. Penuntutan terhadap terdakwa dalam kasus kejahatan narkotika, tidak jarang bagi penuntut untuk menuntut dengan beragam tuntutan meskipun ketentuan pasal yang dibebankan kepada terdakwa adalah sama. Perbedaan tuntutan hukuman dalam penuntutan yang dilakukan oleh penuntut umum tentu didasarkan pada berbagai pertimbangan dan dapat dipertanggungjawabkan. Tulisan ini menggunakan metode penelitian hukum yuridis 17iteratur (penelitian 17iteratur) dengan spesifikasi penelitian deskriptif analitik yang menggunakan data sekunder. Prosedur pengumpulan data adalah dalam bentuk dokumentasi catatan atau kutipan, pencarian 17iterature hukum, buku-buku dan lain-lain yang berkaitan dengan identifikasi masalah baik offline maupun online, yang kemudian dianalisis melalui metode analisis konten (metode analisis konten).
\end{abstract}

\section{Kata Kunci: Jaksa, Penuntutan, Pidana, Narkotia, Denda}

\section{Abstract}

Prosecution of an event or criminal act, including narcotics crime is a function carried out by the Prosecutor's Office, in this case by the public prosecutor. Prosecution is the act of the public prosecutor delegating a criminal case to a competent district court in terms of and according to the method stipulated in the Criminal Procedure Code. The prosecution of the defendant in a narcotics crime case, it is not uncommon for the prosecutor to prosecute with varying demands even though the provisions of the Article charged against the defendant are the same. The difference in demands for punishment in prosecution carried out by public prosecutors is certainly based on various considerations and can be accounted for. This writing uses normative juridical legal research methods (normative research) with descriptive analytical research specifications that use secondary data. The procedure of data collection is in the form of documentation of notes or quotations, search of legal literature, books and others related to the identification of problems both offline and online, which are then analyzed through the content analysis method (centent analysis method).

\section{Keywords: Prosecutor, Prosecution, Crime, Narchotic, Penalty}

\section{PENDAHULUAN}

Peredaran narkotika di Indonesia apabila ditinjau dari aspek yuridis adalah sah keberadaannya. Undang-undang Narkotika hanya melarang penggunaan narkotika tanpa izin oleh undang-undang yang dimaksud. Keadaan demikian ini dalam tataran empirisnya, penggunaan narkotika sering disalahgunakan bukan untuk kepentingan pengobatan dan ilmu pengetahuan. Akan tetapi jauh dari itu, peredaran narkotika dijadikan ajang bisnis yang menjanjikan dan berkembang pesat yang mana kegiatan ini berimbas pada rusaknya fisik maupun psikis mental pemakai narkotika khususnya generasi muda (Siswanto, 2012, h. 5). 


\section{DE IFGA LATA}

Jurnal Ilmu Hukum

FAKULTAS HUKUM UMSU
Penutntutan Requistoir Bagi...(Fauzi Iswahyudi)

Volume 3 Nomor 1, Januari-Juni 2018, 17-28

DOI: $\underline{\text { https://doi.org/10.30596/dll.v3i1.3146 }}$

Penegakan hukum terhadap tindak pidana narkotika telah banyak dilakukan oleh aparat penegak hukum dan telah banyak mendapat putusan hakim. Dengan demikian, penegakan hukum ini diharapkan mampu menjadi faktor penangkal terhadap merebaknya perdagangan gelap serta peredaran narkotika. Namun, dalam kenyataannya justru semakin intensif dilakukan penegakan hukum, semakin meningkat pula peredaran serta perdagangan narkotika tersebut.

Ketentuan perundang-undangan yang mengatur masalah narkotika telah disusun dan diberlakukan, namun demikian kejahatan yang menyangkut tentang narkotika belum dapat diredakan. Dalam banyak kasus terakhir, banyak bandar dan pengedar tertangkap dan mendapat sanksi berat, namun pelaku lain seperti tidak mengacuhkannya bahkan lebih cenderung untuk memperluas daerah operasinya.

Kejahatan narkotika dan obat-obatan terlarang pada masa sekarang telah bersifat transnasional yang dilakukan dengan modus operandi yang tinggi dan teknologi yang canggih, aparat penegak hukum diharapkan mampu mencegah dan menanggulangi kejahatan tersebut guna meningkatkan moralitas dan kualitas sumber daya manusia di Indonesia, khususnya bagi generasi penerus bangsa. Di antara aparat penegak hukum yang juga memiliki peran penting terhadap penegakan hukum terhadap tindak pidana narkotika adalah Badan Narkotika Nasional (BNN), yang diharapkan mampu membantu proses penegakan hukum terhadap tindak pidana narkotika.

Tindak pidana narkotika saat ini tidak lagi dilakukan secara perseorangan melainkan melibatkan banyak orang yang secara bersama-sama, bahkan merupakan satu sindikat yang terorganisasi dengan jaringan yang luas yang bekerja secara rapi dan sangat rahasia baik di tingkat nasional maupun internasional.

Penegakan hukum pidana, termasuk penegakan hukum terhadap tindak pidana narkotika sangat ditentukan oleh bekerjanya lembaga-lembaga sistem peradilan pidana, yaitu Kepolisian, Kejaksaan, Pengadilan, Lembaga Pemasyarakatan (Romli Atmasasmita, 2010, h. 47). Fungsi kepolisian dalam sistem peradilan pidana adalah untuk melakukan penyidikan guna mengumpulkan bukti, dan dengan bukti itu membuat atau menjadi terang tindak pidana yang terjadi serta sekaligus menemukan tersangkanya atau pelaku tindak pidananya. Pada tindakan penyidikan penekanan diletakkan pada tindakan mencari dan menemukan sesuatu peristiwa yang dianggap atau diduga sebagai tindak pidana (M. Yahya Harahap, 2009, h. 109).

Pemeriksaan penyidikan tindak pidana bertujuan untuk menyiapkan hasil pemeriksaan penyidikan sebagai berkas perkara yang akan diserahkan penyidik kepada penuntut umum sebagai instansi yang berwenang melakukan penuntutan terhadap tindak pidana. Berkas hasil penyidikan tersebut kemudian akan dilimpahkan penuntut umum kepada hakim di muka persidangan pengadilan. Oleh karena itu, apabila penyidik berpendapat, pemeriksaan penyidikan telah selesai dan sempurna, maka berkas perkara hasil penyidikan akan diserahkan kepada penuntut umum (M. Yahya Harahap, 2009, h. 355).

Penuntutan terhadap suatu peristiwa atau tindak pidana, termasuk tindak pidana narkotika merupakan fungsi yang dijalankan oleh Kejaksaan, dalam hal ini penuntut umum. Menurut KUHAP, penuntutan adalah tindakan penuntut umum untuk melimpahkan perkara pidana ke pengadilan negeri yang berwenang dalam hal dan menurut cara yang diatur dalam KUHAP dengan permintaan supaya diperiksa dan diputus hakim di sidang pengadilan (Moch. 


\section{DE IFGA LATA}

Jurnal Ilmu Hukum

FAKULTAS HUKUM UMSU
Penutntutan Requistoir Bagi...(Fauzi Iswahyudi)

Volume 3 Nomor 1, Januari-Juni 2018, 17-28

DOI: $\underline{\text { https://doi.org/10.30596/dll.v3i1.3146 }}$

Faisal, 2001, h. 207).

Tindakan penuntutan merupakan tahapan proses pemeriksaan atas suatu tindak pidana yakni melanjutkan tahap pemeriksaan penyidikan ke tingkat proses pemeriksaan pada sidang pengadilan oleh hakim guna mengambil putusan atas perkara tindak pidana. Sebelum masuk tahap pelimpahan dan pemeriksaan di sidang pengadilan, penuntut umum lebih dulu mempelajari berkas perkara hasil penyidikan, apabila dianggap telah sempurna maka kemudian penuntut umum mempersiapkan surat dakwaan dan surat pelimpahan perkara ke pengadilan. Oleh karena itu, sebelum pelimpahan dan pemeriksaan pengadilan, tugas pokok penuntut umum adalah membuat surat dakwaan (M. Yahya Harahap, 2009, h. 386).

Tujuan dan guna surat dakwaan adalah sebagai dasar atau landasan pemeriksaan perkara di dalam sidang pengadilan. Hakim di dalam memeriksa suatu perkara tidak boleh menyimpang dari apa yang dirumuskan dalam surat dakwaan (M. Yahya Harahap, 2009, h. 390). Selain itu surat dakwaan adalah dasar bagi penuntut umum untuk mengajukan tuntutan pada hakim agar memutus perkara tersebut sesuai dengan tuntutan Penuntut Umum.

Penuntutan terhadap terdakwa dalam perkara tindak pidana narkotika, tidak jarang penuntut umum melakukan penuntutan dengan tuntutan yang berbeda-beda meskipun ketentuan Pasal yang didakwakan terhadap terdakwa antara satu perkara dengan perkara lainnya sama. Perbedaan tuntutan hukuman dalam penuntutan yang dilakukan oleh penuntut umum tentunya didasari berbagai pertimbangan dan dapat untuk dipertanggungjawabkan. Sebagai contoh kasus, dapat dilihat pada 2 (dua) putusan Pengadilan Negeri Tebing Tinggi, sebagai berikut:

1. Putusan Pengadilan Negeri Tebing Tinggi Nomor 114/Pid.Sus/2018/PN. Tbt.

Penuntut umum dalam mengajukan terdakwa ke persidangan membuat surat dakwaan dalam bentuk dakwaan alternatif. Dalam dakwaan kesatu, penuntut umum mendakwa Perbuatan terdakwa sebagaimana diatur dan diancam pidana dalam Pasal 114 Ayat 1 UndangUndang Nomor 35 Tahun 2009 Tentang Narkotika. Dalam dakwaan kedua, penuntut umum mendakwa perbuatan terdakwa Sebagaimana diatur dan diancam pidana dalam Pasal 112 Ayat 1 Undang-

Undang Nomor 35 Tahun 2009 Tentang Narkotika. Dalam dakwaan ketiga, penuntut umum mendakwa perbuatan terdakwa sesuai dengan Pasal 127 Ayat 1 huruf a UndangUndang Nomor 35 Tahun 2009 Tentang Narkotika.

Berdasarkan dakwaan yang diajukan penuntutan umum dalam surat dakwaan tersebut, kemudian penuntutan umum mengajukan tuntutan sebagai berikut:

a. Menyatakan terdakwa, terbukti secara sah dan menyakinkan bersalah melakukan tindak pidana "tanpa hak atau melawan hukum menawarkan untuk dijual, menjual, membeli, menerima, menjadi perantara dalam jual beli, menukar atau menyerahkan Narkotika Golongan I bukan Tanaman," sebagaimana diatur dan diancam pidana dalam Pasal 114 Ayat 1 Undang-Undang Nomor 35 Tahun 2009 Tentang Narkotika, dalam Surat Dakwaan atau Kesatu.

b. Menjatuhkan pidana terhadap terdakwa dengan pidana penjara selama 6 (Enam) Tahun 6 (Enam) Bulan dikurangi selama terdakwa berada dalam tahanan sementara dan denda sebesar Rp. 800.000.000.- (delapan ratus juta rupiah) subsider 6 (enam) bulan penjara. 
DEIFGA LATA

Jurnal Ilmu Hukum

FAKULTAS HUKUM UMSU
Penutntutan Requistoir Bagi...(Fauzi Iswahyudi)

Volume 3 Nomor 1, Januari-Juni 2018, 17-28

DOI: $\underline{\text { https://doi.org/10.30596/dll.v3i1.3146 }}$

c. Menetapkan barang bukti berupa: a. 1 (satu) bungkus plastik transparan berisi serbuk kristal diduga Narkotika jenis shabu b. 1 (satu) lembar kertas timah rokok warna merah. c. 2 (dua) buah pipet plastic. d. 1 (satu) Unit HP Merk Nokia. Seluruhnya Dirampas Untuk Dimusnahkan. e. 1 (satu) Unit Sepeda motor Honda jenis Beat warna putih No. Plat Polisi BK 4469 NAQ, dikembalikan kepada Pemiliknya yang Berhak.

d. Memerintahkan agar terdakwa tetap ditahan dan menetapkan agar terdakwa membayar biaya perkara sebesar Rp.2.000,- (dua ribu rupiah).

\section{Putusan Pengadilan Negeri Tebing Tinggi Nomor 73/Pid.Sus/2018/PN. Tbt.}

Penuntut umum dalam mengajukan terdakwa ke persidangan membuat surat dakwaan dalam bentuk dakwaan alternatif. Dalam dakwaan kesatu, penuntut umum mendakwa Perbuatan terdakwa sebagaimana diatur dan diancam pidana dalam Pasal 114 Ayat 1 UndangUndang Nomor 35 Tahun 2009 Tentang Narkotika. Dalam dakwaan kedua, penuntut umum mendakwa perbuatan terdakwa Sebagaimana diatur dan diancam pidana dalam Pasal 112 Ayat 1 Undang-Undang Nomor 35 Tahun 2009 Tentang Narkotika. Dalam dakwaan ketiga, penuntut umum mendakwa perbuatan terdakwa sesuai dengan Pasal 127 Ayat 1 huruf a Undang-Undang Nomor 35 Tahun 2009 Tentang Narkotika.

Berdasarkan dakwaan yang diajukan penuntutan umum dalam surat dakwaan tersebut, kemudian penuntutan umum mengajukan tuntutan sebagai berikut:

a. Menyatakan Aminsyah Siregar Alias Amin telah terbukti secara sah menurut hukum bersalah melakukan tindak pidana "tanpa hak dan melawan hukum memiliki, menyimpan atau menguasai Narkotika golongan I bukan tanaman berupa sabu sebagaimana diatur dan diancam pidana dalam 112 Ayat 1 Undang-Undang Nomor 35 Tahun 2009 Tentang Narkotika dalam dakwaan kedua.

b. Menghukum terdakwa Aminsyah Siregar Alias Amin dengan pidana penjara selama 10 (Sepuluh) Tahun dengan dikurangi selama terdakwa berada dalam tahanan dengan perintah terdakwa tetap ditahan, dan denda sebesar Rp. 800.000.000,- (delapan ratus juta rupiah) Subsidair 6 (enam) bulan Penjara.

c. Menyatakan barang bukti berupa: 1 (satu) bungkus plastik klip transparan berisi serbuk warna putih dengan berat bruto 4,90 gram, netto 4,38 gram, 1 (satu) buah amplop warna putih, dirampas untuk dimusnahkan.

d. Menetapkan agar terdakwa membayar biaya perkara sebesar Rp. 2.000 (dua ribu rupiah).

Contoh surat dakwaan dan tuntutan yang terdapat dalam kedua putusan Pengadilan Negeri Tebing Tinggi di atas, terlihat bahwa dalam perkara tindak pidana narkotika penuntut umum lazim membuat dan mendakwa terdakwa dengan Pasal-Pasal yang sama dan dalam bentuk surat dakwaan yang sama pula, tetapi mengajukan tuntutan yang berbeda terhadap terdakwa.

Terkait dengan penuntutan requistoir bagi pelaku tindak pidana narkotika, sehingga yang menjadi fokus permasalahn dalam penulisan ini adalah Bagaimana pengaturan penuntutan hukuman yang dituntut Jaksa Penuntut Umum dalam requisitoir bagi pelaku tindak pidana narkotika. dengan harapan tulisan ini dapat bermanfaat baik secara teori maupun praktis bagi khalayak luas terkait dengan penuntutan requistoir bagi pelaku tindak 
DEIEGA LATA

Jurnal Ilmu Hukum

FAKULTAS HUKUM UMSU
Penutntutan Requistoir Bagi...(Fauzi Iswahyudi)

Volume 3 Nomor 1, Januari-Juni 2018, 17-28

DOI: $\underline{\text { https://doi.org/10.30596/dll.v3i1.3146 }}$

pidana narkotika.

\section{METODE PENELITIAN}

Penulisan ini menggunakan metode penelitian hukum yuridis normatif (normatif research), yaitu penelitian hukum yang dilakukan dengan cara meneliti bahan pustaka atau data skunder (Seokanto dan Sri Muji, 2003, h. 15). Spesifikasi penelitian dalam penulisan ini berupa penelitian deskriptif analistis. Deskriptif adalah menunjukan komparasi atau hubungan seperangkat data dengan seperangkat data yang lain, dan maksudnya adalah untuk memberikan gambaran, menelaah, menjelaskan dan menganalisis (Soekanto, 1996, h. 63).

Sesuai jenis dan sifat penelitiannya, maka sumber data yang digunakan dalam penulisan ini adalah data skunder yang terdiri dari bahan hukum primer berupa Undang-Undang Dasar 1945 (UUD 1945), Undang-Undang Nomor 35 Tahun 2009 Tentang Narkotika, UndangUndang Nomor 16 Tahun 2004 tentang Kejaksaan Republik Indonesia, Undang-Undang Nomor 8 Tahun 1981 Tentang Kitab Undang Hukum Acara Pidana, Kitab Undang-undang Hukum Pidana (KUHP), putusan Nomor 73/Pid.Sus/2018/PN.Tbt, Surat Edaran Mahkamah Agung (SEMA) Republik Indonesia Nomor 4 Tahun 2010 tentang Penempatan Penyalahgunaan, Korban Penyalahgunaan dan Pecandu Narkotika ke Dalam Lembaga Rehabilitasi Medis dan Rehabilitasi Sosial jo SEMA Nomor 7 Tahun 2009 Tentang menempatkan Pemakai Narkoba ke dalam Panti Terapi dan Rehabilitasi. Bahan hukum sekunder terdiri dari buku-buku, jurnal ilmiah, makalah dan artikel ilmiah yang dapat memberi penjelasan tentang bahan hukum primer. Bahan hukum tersier; berupa Kamus Besar Bahasa Indonesia (KBBI) dan lain sebagainya dalam menemukan defenisi dari istilah-istilah dalam membahas hal yang terkait dengan penuntutan requistoir bagi pelaku tindak pidana narkotika.

Prosedur yang digunakan untuk mengumpulkan data dalam penilitian ini berupa dokumentasi yaitu pedoman yang digunakan berupa catatan atau kutipan, penelusuran literatur hukum, buku-buku dan lainnya yang bertalian dengan identifikasi masalah dalam penilitian ini dengan cara offline maupun online. Analisa bahan hukum dilakukan dengan menggunakan metode analisa konten (centent analysis method) yang dilakukan dengan menguraikan materi peristiwa hukum atau produk hukum secara rinci guna memudahkan interpretasi dalam pembahasan (Marzuki, 2011, h. 171).

\section{PEMBAHASAN}

\section{Pengaturan Penuntutan Hukuman Yang Dituntut Jaksa Penuntut Umum Dalam Requisitoir Bagi Pelaku Tindak Pidana Narkotika}

Penuntutan terhadap setiap tindak pidana merupakan kewenangan yang dimiliki oleh lembaga kejaksaan, yakni menjadi kewenangan dari penuntut umum. Hal ini sesuai dengan ketentuan yang diatur dalam Undang-Undang Nomor 16 Tahun 2004 tentang Kejaksaan Republik Indonesia.

Pasal 2 Ayat 1, 2 dan Ayat 3 Undang-Undang Nomor 16 Tahun 2004 tentang Kejaksaan Republik Indonesia, menyatakan bahwa: Kejaksaan Republik Indonesia yang selanjutnya dalam Undang-Undang ini disebut Kejaksaan adalah lembaga pemerintahan yang melaksanakan kekuasaan negara di bidang penuntutan serta kewenangan lain berdasarkan undang-undang. Kekuasaan negara dalam melakukan penuntutan tersebut dilaksanakan secara merdeka dan merupakan suatu kesatuan yang tidak dapat dipisahkan. 


\section{DE IFGA LATA}

Jurnal Ilmu Hukum

FAKULTAS HUKUM UMSU
Penutntutan Requistoir Bagi...(Fauzi Iswahyudi)

Volume 3 Nomor 1, Januari-Juni 2018, 17-28

DOI: $\underline{\text { https://doi.org/10.30596/dll.v3i1.3146 }}$

Selanjutnya dalam Pasal 3 Undang-Undang Nomor 16 Tahun 2004 dinyatakan bahwa pelaksanaan kekuasaan negara sebagaimana dimaksud dalam Pasal 2 diselenggarakan oleh Kejaksaan Agung, Kejaksaan Tinggi, dan Kejaksaan Negeri.

Berdasarkan ketentuan Pasal di atas, dapat dipahami bahwa Kejaksaan menurut Undang-Undang Nomor 16 Tahun 2004 tentang Kejaksaan Republik Indonesia, adalah lembaga pemerintahan yang melaksanakan kekuasaan negara di bidang penegakan hukum dengan berpegang pada peraturan perundang-undangan dan kebijakan yang ditetapkan oleh pemerintah.

Pelaksanaan dari kekuasaan negara tersebut diselenggarakan oleh Kejaksaan Agung, Kejaksaan tinggi, dan Kejaksaan negeri. Sebagai suatu badan yang berwenang dalam penegakan hukum dan keadilan, kejaksaan dipimpin oleh jaksa agung yang dipilih oleh dan bertanggungjawab kepada presiden. Kejasaan Agung, Kejaksaan Tinggi, Kejaksaan Negeri merupakan kekuasaan Negara khususnya di bidang Penuntutan, di mana semuanya merupakan satu kesatuan yang utuh yang tidak dapat dipisahkan.

Kejaksaan adalah suatu lembaga, badan, institusi pemerintah yang menjalankan kekuasaan negara di bidang penuntutan dan kewenangan lain. Sementara orang yang melakukan tugas, fungsi, dan kewenangan itu disebut Jaksa. Hal ini ditegaskan dalam Pasal 1 Ayat 1 Undang-Undang Nomor 16 tahun 2004, Tentang Kejaksaan yaitu, "Jaksa adalah pejabat fungsional yang diberi wewenang oleh undang-undang untuk bertindak sebagai penuntut umum dan pelaksanaan putusan pengadilan yang telah memperoleh kekuatan hukum tetap serta wewenang lain berdasarkan undang-undang”. Lebih lanjut, di dalam Ayat 2 disebutkan bahwa yang dimaksud dengan penuntut umum adalah Jaksa yang diberi wewenang untuk melakukan penuntutan dan melaksanakan penetapan hakim. Kemudian di dalam Ayat 3 dijelaskan bahwa penuntutan adalah tindakan penuntut umum melimpahkan perkara ke pengadilan negeri yang berwenang dalam hal dan menurut cara yang diatur dalam Hukum Acara Pidana dengan permintaan supaya diperiksa dan diputus oleh hakim di sidang pengadilan.

Berdasaran ketentuan Pasal 1 Ayat 1, 2 dan 3 Undang-Undang Nomor 16 Tahun 2004 tentang Kejaksaan, maka dapat dipahami bahwa selain tugasnya di bidang penuntutan, juga diberi kewenangan lain oleh undang-undang misalnya sebagai Jaksa Pengacara Negara, Eksekutor putusan pengadilan yang telah memperoleh kekuatan hukum tetap, sebagai penyelidik tindak pidana tertentu.

Kedudukan dan peran Kejaksaan Republik Indonesia sebagai lembaga Pemerintah yang melaksanakan kekuasaan negara di bidang penuntutan harus bebas dari segala pengaruh kekuasaan pihak manapun. Eksistensi kejaksaan dikehendaki sebagai lembaga aparat penegak hukum di bidang penuntutan mewujudkan rasa keadilan, kepastian hukum, dan kemanfaatan hukum dalam kehidupan bermasyarakat, berbangsa, dan bernegara. (Yesmil Anwar dan Adang, 2009, h. 189). Hukum dan penegakan hukum merupakan sebagaian faktor penegakan hukum yang tidak bisa diabaikan karena jika diabaikan akan menyebabkan tidak tercapainya penegakan hukum yang diharapkan (Soerjono Soekanto, 2010, h. 5).

Kewenangan Jaksa melakukan penuntutan diatur pula di dalam KUHAP, sebagaimana disebutkan dalam Pasal 1 angka 7 yang berbunyi "Penuntutan adalah tindakan penuntut umum untuk melimpahkan perkara pidana ke Pengadilan Negeri yang berwenang dalam hal 
Jurnal Ilmu Hukum

FAKULTAS HUKUM UMSU
Penutntutan Requistoir Bagi...(Fauzi Iswahyudi)

Volume 3 Nomor 1, Januari-Juni 2018, 17-28

DOI: $\underline{\text { https://doi.org/10.30596/dll.v3i1.3146 }}$

dan menurut cara yang diatur dalam undang-undang ini dengan permintaan supaya diperiksa dan diputus oleh hakim di sidang pengadilan".

Undang-Undang Kejaksaan Nomor 16 Tahun 2004 dipandang lebih kuat dalam menetapkan kedudukan dan peran Kejaksaan Republik Indonesia sebagai lembaga negara pemerintah yang melaksanakan kekuasaan negara dibidang penuntutan. Pelaksanaan penuntutan oleh Jaksa sebagai bagian dari penegakan hukum. Penegakan hukum secara konkret adalah berlakunya hukum positif dalam praktik sebagaimana seharusnya patut dipatuhi. Karena itu, memberikan keadilan dalam suatu perkara berarti memutuskan hukum in concreto dalam mempertahankan dan menjamin ditaatinya hukum materiil dengan menggunakan cara prosedural yang ditetapkan oleh hukum formal. Artinya, penegakan hukum merupakan upaya untuk menegakan keentuan hukum pidana materil dan formil.

Penegakan hukum pidana materil dalam kaitannya dengan penelitian ini, yaitu penegakan hukum terhadap pelanggaran Undang-Undang Nomor 35 Tahun 2009 Tentang Narkotika. Sebagai Undang-Undang Khusus (lex specialis) yang mengatur tentang kejahatan narkotika, Undang-Undang Nomor 35 Tahun 2009 tentunya mengatur mengenai delik pidana dan sanksi bagi setiap orang yang melanggar atau melakukan delik pidana yang telah dirumuskan dalam Bab XV ketentuan pidana undang-undang ini. Delik pidana dalam undangundang ini dirumuskan mulai Pasal 111 sampai dengan Pasal 147. Jadi, di dalam melakukan penuntutan terhadap terdakwa tindak pidana narkotika, Jaksa mengacu pada ketentuan Undang-Undang Nomor 35 Tahun 2009 Tentang Narkotika sebagai hukum pidana materil yang mengatur tentang tindak pinda narkotika.

Penegakan hukum pidana materil, maka tentunya dibutuhkan hukum pidana formil sebagai pedoman dalam penegakan hukum pidana materil. Ketentuan hukum pidana formil di Indonesia secara umum diatur dalam Undang-Undang Nomor 8 Tahun 1981 Tentang Kitab Undang-Undang Hukum Acara Pidana. dengan demikian, Penuntutan terhadap tindak pidana narkotika secara umum berpedoman pada KUHAP yang menentukan bahwa pelaksanaan penuntutan dilaksanakan oleh Jaksa Penuntut Umum sebagaiman disebutkan dalam Pasal 1 angka 7 KUHAP.

Bab XV Undang-Undang Nomor 35 Tahun 2009 tentang Narkotika menentukan beberapa Pasal mengenai rumusan delik pidana narkotika yang diatur mulai dari Pasal $111 \mathrm{~s} / \mathrm{d}$ Pasal 147. Dilihat dari rumusan Pasal-Pasal delik pidana dalam ketentuan pidana undangundang ini, maka penerapan Pasal-Pasal yang menjadi delik pidana dalam undang-undang ini dapat dilihat dari jenis narkotikanya dan proses kejahatannya. Dilihat dari jenis narkotikanya, Undang-Undang Nomor 35 Tahun 2009, membedakan jenis narkotika ke dalam 3 golongan, yaitu narkotika Golongan I, Golongan II dan Golongan III.

Dilihat dari perbuatan atau proses kejahatan berkaitan dengan pelanggaran delik narkotika, dapat dilihat dari klasifikasi peran pihak-pihak yang berkaitan dengan narkotika. Dalam Undang-Undang Nomor 35 Tahun 2009 Tentang narkotika telah diatur mengenai peran dari pelaku dan sanksinya. Sanksi pidana bagi pihak yang memproduksi, pengedar/penjual atau perantara tentu lebih berat dari pada pihak yang hanya menggunakan narkotika. Namun, dalam klasifikasi pengedar pun dibagi lagi sesuai perannya, apakah sebagai pihak bandar besar yang memproduksi narkotika, atau hanya sebagai penjual saja, ataupun sebagai kurir atau perantara. 


\section{DE IFGA LATA}

Jurnal Ilmu Hukum

FAKULTAS HUKUM UMSU
Penutntutan Requistoir Bagi...(Fauzi Iswahyudi)

Volume 3 Nomor 1, Januari-Juni 2018, 17-28

DOI: $\underline{\text { https://doi.org/10.30596/dll.v3i1.3146 }}$

Pemahaman terhadap pelanggaran jenis narkotika, perbuatan atau peran dari tersangka/terdakwa dalam penerapan Pasal-Pasal undang-undang narkotika adalah penting, sebab berkaitan dengan penerapan Pasal-Pasal yang dilanggar oleh tersangka/terdakwa dalam proses penyidikan oleh penyidik dan penuntutan oleh penuntut umum. M. Yahya Harahap menjelaskan bahwa:

Tujuan pemeriksaan penyidikan tindak pidana menyiapkan hasil pemeriksaan penyidikan sebagai 'berkas perkara' yang akan diserahkan penyidik kepada penuntut umum sebagai instansi yang bertindak dan berwenang melakukan penuntutan terhadap tindak pidana. Berkas hasil penyidikan itu kemudian dilimpahkan penuntut umum kepada hakim di muka persidangan pengadilan. Oleh karena itu, apabila penyidik berpendapat, pemeriksaan penyidikan telah selesai dan sempurna, secepatnya mengirimkan berkas perkara hasil penyidikan kepada penuntut umum (M. Yahya Harahap, 2009, h. 355).

Kesempurnaan pemeriksaan penyidikan amat penting diperhatikan. Hal ini sesuai dengan sistem penahapan pemeriksaan yang dianut KUHAP, yang telah mengatur diferensiasi fungsional diantara para instansi penegak hukum. kekurangsempurnaan pemeriksaan penyidikan masih bisa diperbaiki oleh penuntut umum yang berkedudukan sebagai penyidik lanjutan dan mengkoordinasi pemeriksaan tindakan penyidikan. Oleh karena itu, apabila penuntut umum berpendapat pemeriksaan belum sempurna, dan belum dapat diajukan ke persidangan pengadilan, maka berkas penyidikan dikembalikan kepada penyidik untuk menambah dan menyempurnakan penyidikan sesuai dengan petunjuk yang diberikan penuntut umum (M. Yahya Harahap, 2009, h. 357).

Berdasarkan penjelasan di atas, dapat dikatakan bahwa dalam penuntutan terhadap tindak pidana narkotika oleh penuntut umum sangat erat kaitannya dengan keberhasilan dari pemeriksaan dan penyidikan yang dilakukan oleh penyidik. Di sinilah dituntut adanya hubungan yang serasi dan serempak dari sub sistem peradilan pidana (criminal justice system) dalam proses penegakan hukum. Sistem peradilan pidana (SPP) kini telah menjadi suatu istilah yang menunjukkan sebagai mekanisme kerja dalam penanggulangan kejahatan dengan mengunakan dasar pendekatan system (Romli Atmasasmita, 2010, h. 2). Sistem peradilan pidana, menurut Remington dan Ohlin adalah:

Criminal justice system dapat diartikan sebagai pemakaian pendekatan sistem terhadap mekanisme administrasi peradilan pidana, dan peradilan pidnaa sbeagai suatu sistem merupakan hasil interaksi antara peraturan perundang-undangan, praktik administrasi dan sikap atau tingkah laku sosial. Pengertian sistem itu sendiri mengandung implikasi sebagai suatu proses interaksi yang dipersiapkan secara rasional dan dengan cara efisien untuk memberikan hasil tertentu dengan segala keterbatasannya (Romli Atmasasmita, 2010, h. 2).

Pemahaman tentang sistem peradilan pidana dapat dilihat dari unsur kata yang melekat dalam sistem peradilan pidana itu sendiri. Sistem, berarti sebagai suatu susunan atau jaringan tertentu pada sebuah sistem yang didalamnya terdapat komponen-komponen yan merupakan bagian dari sub-sub yang kemudian menyatu dan membentuk sistem. Masing-masing komponen atau sub-sub sistem yang satu tergantung pada komponen atau sub sistem lainnya, sehingga jika salah satu komponen hilang, maka sistem tidak dapat berjalan. 


\section{DE IFGA LATA}

Jurnal Ilmu Hukum

FAKULTAS HUKUM UMSU
Penutntutan Requistoir Bagi...(Fauzi Iswahyudi)

Volume 3 Nomor 1, Januari-Juni 2018, 17-28

DOI: $\underline{\text { https://doi.org/10.30596/dll.v3i1.3146 }}$

Berdasarkan uraian di atas, dapat dipahami bahwa sistem peradilan pidana sebagai upaya penanggulangan kejahatan yang bersifat penal menggunakan hukum pidana sebagai sarana utama, baik hukum pidana materil maupun formal termasuk pelaksanaan pidananya. Sistem peradilan pidana yang terdiri dari komponen Kepolisian, Kejaksaan, Pengadilan dan Lembaga Pemasyarakatan, merupakan suatu proses yang diharapkan masyarakat untuk dapat bergerak secara terpadu dalam mencapai suatu tujuan yang dikehendaki bersama, yaitu mencegah terjadinya kejahatan dan mewujudkan kesejahteraan masyarakat (Tholib Efendi, 2010, h. 13).

Penuntutan hukuman bagi pelaku tindak pidana narkotika tidak terlepas dari hubungan antara subsistem peradilan pidana dalam mencapai tujuan dari sistem peradilan pidana. Secara umum, sistem peradilan pidana di Indonesia memiliki 2 (dua) tujuan besar, yaitu untuk melindungi masyarakat dan menegakkan hukum. Selain dua tujuan tersebut, sistem peradilan pidana memiliki beberapa fungsi penting, yaitu :

a. Mencegah terjadinya kejahatan;

b. Menindak pelaku tindak pidana dengan memberikan pengertian terhadap pelaku tindak pidana di mana pencegahan tidak efektif;

c. Peninjauan ulang terhadap legalitas ukuran pencegahan dan penindakan;

d. Putusan pengadilan untuk menentukan bersalah atau tidak bersalah terhadap orang yang ditahan;

e. Disposisi yang sesuai dengan seseorang yang dinyatakan bersalah;

f. Lembaga koreksi oleh alat-alat negara yang disetujui oleh masyarakat terhadap perilaku mereka yang telah melanggar hukum pidana (Andi Sofyan dan Abd Azis, 2014, h. 13-14)

Mencapai tujuan dari sistem peradilan pidana, maka harus dipahami bahwa dalam sistem peradilan pidana (criminal justice system) di dalamnya terkandung prosedur peradilan pidana (criminal justice proces), sehingga antara proses peradilan pidana memiliki keterikatan dengan lembaga, peraturan dan masyarakat yang menunjang berlakunya hukum pidana materiil dan formal untuk menunjang terlaksananya sistem peradilan pidana.

Di bidang hukum formil, yaitu hukum acara pidana, bangsa Indonesia merupakan salah satu negara yang mampu membuat kodifikasi peraturan perundang-undangan hukum acara pidana yaitu dengan dikeluarkannya Undang-undang Nomor 8 Tahun 1981 tentang Kitab Undang-Undang Hukum Acara Pidana (KUHAP).

Diterbitkannya Undang-Undang Nomor 8 Tahun 1981 Tentang Kitab Undang Hukum Acara Pidana bertujuan agar masyarakat dapat menghayati hak- dan kewajibannya dan agar dapat dicapai serta ditingkatkan pembinaan sikap para pelaksana penegak hukum sesuai dengan fungsi dan wewenang masing-masing ke arah tegak mantapnya hukum, keadilan dan perlindungan yang merupakan pengayoman terhadap keluhuran harkat serta martabat manusia, ketertiban dan kepastian hokum (M. Karjadi dan R. Soesilo, 2017, h. 9).

Andi Hamzah mengatakan bahwa terciptanya KUHAP, maka untuk pertama kalinya di Indonesia diadakan kodifikasi dan unifikasi yang lengkap dalam arti meliputi seluruh proses pidana dari awal (mencari kebenaran) sampai pada kasasi di Mahkamah Agung (Andi Hamzah, 2005:3). Lebih lanjut, Andi Hamzah menambahkan bahwa Polisi, jaksa dan hakim tidak boleh semaunya menjalankan acara pidana, tetapi harus berdasarkan ketentuan Undang- 
DEIFGA LATA

Jurnal Ilmu Hukum

FAKULTAS HUKUM UMSU
Penutntutan Requistoir Bagi...(Fauzi Iswahyudi)

Volume 3 Nomor 1, Januari-Juni 2018, 17-28

DOI: $\underline{\text { https://doi.org/10.30596/dll.v3i1.3146 }}$

undang yaitu KUHAP dan perundang-undangan di luar KUHAP yang mengandung ketentuan acara yang menyimpang (Andi Hamzah, 2005, h. 2).

Peringatan lebih keras disampaikan oleh M. Yahya Harahap, yang mengatakan bahwa KUHAP pada dasarnya telah mengangkat dan menempatkan tersangka atau terdakwa dalam kedudukan yang berderajat, yang harus diperlakukan sesuai dengan nilai-nilai luhur kemanusiaan. Oleh karena itu, dalam pelaksanaan penegakan hukum terhadap tersangka atau terdakwa, tidak boleh ditelanjangi hak asasi utama yang melekat pada dirinya (M. Yahya Harahap, 2009, h. 1-2).

Di dalam KUHAP telah dijelaskan secara terperinci mengenai tugas-tugas dari mulai kepolisian sebagai Penyidik, Kejaksaan sebagai Penuntut Umum dan pelaksana eksekusi putusan pengadilan (eksekutor) dan hakim sebagai pemutus perkara pidana, dan Lembaga Pemasyarakatan/Rumah Tahanan.

Pedoman pelaksanaan KUHAP telah menyatukan antara tujuan dan tugas atau fungsi hukum acara pidana, namun seharusnya tujuan hukum acara pidana dari segi teoretis diparalelkan dengan hukum pada umumnya yaitu untuk mencapai kedamaian dalam masyarakat. Selanjutnya, dalam operasionalisasi tujuan hukum acara pidana dari segi praktis adalah untuk mendapatkan suatu kenyataan yang berhasil mengurangi keresahan dalam masyarakat berupa aksi sosial yang bersifat rasional dan konstruktif yang didasari pada kebenaran hukum dan keadilan hokum (M. Yahya Harahap, 2009, h. 62).

Tujuan hukum acara pidana dalam konsiderans KUHAP, yaitu bahwa pembangunan hukum nasional di bidang hukum acara pidana adalah agar masyarakat menghayati hak dan kewajibannya dan untuk meningkatkan pembinaan sikap para pelaksana penegak hukum sesuai dengan fungsi dan wewenang masing-masing ke arah tegaknya hukum, keadilan dan perlindungan terhadap harkat dan martabat manusia, ketertiban serta kepastian hukum demi terselenggaranya negara hukum sesuai dengan Undang-Undang Dasar 1945 (M. Yahya Harahap, 2009, h. 9).

Berdasarkan konsiderans hukum c KUHAP, maka dapat dijelaskan landasan tujuan KUHAP, sebagaimana dikemukakan oleh Yahya Harahap, sebagai berikut:

a. Peningkatan kesadaran hukum masyarakat, artinya menjadi setiap anggota masyarakat mengetahui apa haknya yang diberikan hukum dan undang-undang kepadanya serta apa pula kewajiban yang dibebankan hukum kepada dirinya.

b. Meningkatkan sikap mental aparat penegak hukum, yaitu :

1) Meningkatkan pembinaan ketertiban aparat penegak hukum sesuai dengan fungsi dan wewenang masing-masing;

2) Peningkatan kecerdasan dan keterampilan teknis para aparat penegak hukum; dan

3) Pejabat penegak hukum yang bertakwa kepada Tuhan Yang Maha Esa serta bermoral perikemanusiaan yang adil dan beradab.

c. Tegaknya hukum dan keadilan di tengah-tengah masyarakat, yaitu :

1) Menegakkan hukum yang berlandaskan sumber Pancasilan, Undang-Undang Dasar 1945, dan segala hukum dan perundang-undangan yang tidak bertentangan dengan sumber hukum dan nilai-nilai kesadaran yang hidup dalam masyarakat.

2) Menegakkan nilai-nilai yang terkandung dalam falsafah Pancasila dan UndangUndang Dasar 1945 serta segala nilai-nilai yang terdapat pada hukum dan perundang-undangan yang lain, yang nilainya aspiratif dengan nilai dan rasa keadilan masyarakat, dan 
DEIFGA LATA

Jurnal Ilmu Hukum

FAKULTAS HUKUM UMSU
Penutntutan Requistoir Bagi...(Fauzi Iswahyudi)

Volume 3 Nomor 1, Januari-Juni 2018, 17-28 DOI: $\underline{\text { https://doi.org/10.30596/dll.v3i1.3146 }}$

3) Agar tidak bergeser dari KUHAP yang telah ditentukan sebagai pedoman tata cara pelaksanaan dan asas-asas prinsip hukumnya.

d. Melindungi harkat martabat manusia, artinya manusia sebagai hamba Tuhan dan sebagai mahkluk yang sama derajatnya dengan manusia lainnya, harus ditempatkan pada keluruhan harkat dan martabatnya.

e. Menegakkan ketertiban dan kepastian hukum, maksudnya tujuan kehidupan masyarakat ialah mencari dan mewujudkan ketentraman atau ketertiban yaitu kehidupan bersama antara sesama anggota masyarakat (M. Yahya Harahap, 2009, h. 62).

Berdasarkan uraian di atas, dapat dipahami bahwa dalam proses peradilan pidana, baik itu pada tahap penyidikan, penuntutan maupun pemeriksaan di muka persidangan harus tetap memperhatikan hak-hak dari tersangka/terdakwa. Dalam hal ini penegak hukum yang tergabung dalam sistem peradilan pidana harus berupa untuk mewujudkan tujuan dari sistem peradilan pidana.

Sistem peradilan pidana (criminal justice system) hakikatnya merupakan sistem yang berupaya untuk menjaga keseimbangan perlindungan kepentingan, baik kepentingan negara, masyarakat maupun individu termasuk kepentingan pelaku tindak pidana dan korban kejahatan (Romli Atmasasmita, 2010, h. 6).

\section{KESIMPULAN DAN SARAN Kesimpulan}

Pengaturan penuntutan hukuman yang dituntut Jaksa Penuntut Umum dalam requisitoir bagi pelaku tindak pidana narkotika mengacu pada Undang-Undang Nomor 35 Tahun 2009 Tentang Narkotika sebagai ketentuan hukum pidana materiil yang menjadi dasar bagi penuntut dalam menentukan pasal-pasal yang akan didakwakan terhadap terhadap terdakwa. Sedangkan mekanisme pengajuan tuntutan atau hukuman terhadap terdakwa, penuntut umum mengacu pada Undang-Undang Nomor 8 Tahun 1981 Tentang Kitab Undang-Undang Hukum Acara (KUHAP) sebagai pedoman atau hukum pidana formal yang mengatur mekanisme penuntutan terhadap terdakwa oleh penuntut umum.

\section{Saran}

Perlu adanya pemahaman penuntut umum terhadap rentetan peristiwa pidana dan buktibukti yang mendukung sebelum merumuskan surat dakwaan, sehingga perumusan surat dakwaan tersebut sesuai dengan fakta-fakta peristiwa yang dilakukan oleh tersangka/terdakwa. Mengingat dasar dalam mengajukan tuntutan terhadap terdakwa, yang menjadi dasar atau acuan bagi penuntut umum adalah pasal-pasal yang didakwakan dalam surat dakwaan. 
Jurnal Ilmu Hukum

FAKULTAS HUKUM UMSU
Penutntutan Requistoir Bagi...(Fauzi Iswahyudi)

Volume 3 Nomor 1, Januari-Juni 2018, 17-28

DOI: $\underline{\text { https://doi.org/10.30596/dll.v3i1.3146 }}$

\section{DAFTAR PUSTAKA}

Anwar, Yesmil dan Adang. (2009). Sistem Peradilan Pidana. Konsep. Komponen \& Pelaksanaannya Dalam Penegakan Hukum di Indonesia. Bandung: Widya Padjadjaran.

Atmasasmita, Romli. (2010). Sistem Peradilan Pidana Kontemporer. Jakarta: Prenada Kencana Media Group.

Efendi, Tholib. (2010). Sistem Peradilan Pidana. Perbandingan Komponen dan Proses Sistem Peadilan Pidana di Beberapa Negara. Yokyakarta: Pustaka Yustisia.

Faisal, Moch. (2001). Hukum Acara Pidana Dalam Teori \& Praktek. Bandung: Mandar Maju Hamzah, Andi. (2005). Hukum Acara Pidana Indonesia. Edisi Ketiga. Jakarta: Sinar Grafika.

Harahap, Yahya. M. 2009. Pembahasan Permasalahan dan Penerapan KUHAP. Penyidikan dan Penuntutan. Jakarta: Sinar Grafika.

Hartanti, Evi. (2005). Tindak Pidana Korupsi. Jakarta: Sinar Grafika.

Karjadi, M., \& Soesilo, R. (2017). Kitab Undang-Undang Hukum Acara Pidana. Jakarta: Politea

Kitab Undang-undang Hukum Pidana (KUHP)

Marzuki, Peter Mahmud. (2011). Penelitian Hukum. Jakarta: Kencana Prenada Media Group. Putusan Nomor 73/ Pid.Sus/2018/PN.Tbt.

Seokanto, Sorejono., \& Muji, Sri. (1996). Pengantar Penelitian Hukum. 1996. Jakarta: UI Press.

Seokanto, Sorejono., \& Muji, Sri. (2003). Penelitian Hukum Normatif Suatu Tinjauan Singkat. Jakarta: Rajawali Pers.

Siswanto. (2012). Politik Hukum Dalam Undang-Undang Narkotika No. 35 Tahun 2009. Jakarta: Rineka Cipta.

Soekanto, Soerjono. (2010). Faktor-Faktor yang Mempengaruhi Penegakan Hukum. Jakarta: Rajawali Pers.

Sofyan, Andi., \& Abd, Azis. (2014). Hukum Acara Pidana Suatu Pengantar. Prenada Kencana Media Group.

Surat Edaran Mahkamah Agung Republik Indonesia Nomor 4 Tahun 2010 tentang Penempatan Penyalahgunaan. Korban Penyalahgunaan dan Pecandu Narkotika ke Dalam Lembaga Rehabilitasi Medis dan Rehabilitasi Sosial jo SEMA Nomor 07 Tahun 2009 Tentang menempatkan Pemakai Narkoba ke Dalam Panti Terapi dan Rehabilitasi.

Undang-Undang Dasar 1945.

Undang-Undang Nomor 16 Tahun 2004 tentang Kejaksaan Republik Indonesia.

Undang-Undang Nomor 35 Tahun 2009 Tentang Narkotika.

Undang-Undang Nomor 8 Tahun 1981 Tentang Kitab Undang Hukum Acara Pidana. 